Article

\title{
Tepary Bean (Phaseolus acutifolius) Lectins Induce Apoptosis and Cell Arrest in G0/G1 by P53(Ser46) Phosphorylation in Colon Cancer Cells
}

\author{
Ulisses Moreno-Celis ${ }^{1} \oplus$, F. Josué López-Martínez ${ }^{1}$, Ricardo Cervantes-Jiménez ${ }^{1}$, \\ Roberto Augusto Ferríz-Martínez ${ }^{1}$ (D) Alejandro Blanco-Labra ${ }^{2}$ and Teresa García-Gasca ${ }^{1, * \mathbb{D}}$ \\ 1 Facultad de Ciencias Naturales, Universidad Autónoma de Querétaro, Av. de las Ciencias s/n. Juriquilla, \\ Querétaro CP 76230, Mexico; ulisses.morenoc@gmail.com (U.M.-C.); bioxtremo@hotmail.com (F.J.L.-M.); \\ ricardocervantesjimenez@gmail.com (R.C.-J.); raffer712701@gmail.com (R.A.F.-M.) \\ 2 Depto de Biotecnología y Bioquímica, Centro de Investigación y de estudios Avanzados del IPN-Unidad \\ Irapuato, Guanajuato CP 36821, Mexico; alejandroblancolabra@gmail.com \\ * Correspondence: tggasca@uaq.edu.mx; Tel.: +52-442-192-1200 (ext. 5308)
}

Received: 30 November 2019; Accepted: 17 February 2020; Published: 25 February 2020

\begin{abstract}
A Tepary bean lectin fraction (TBLF) has been studied because it exhibits differential cytotoxic and anticancer effects on colon cancer. The present work focuses on the evaluation of the apoptotic mechanism of action on colon cancer cells. Initially, lethal concentrations $\left(\mathrm{LC}_{50}\right)$ were obtained for the three studied cell lines (HT-29, RKO and SW-480). HT-29 showed the highest LC $_{50}$, 10 and 100 times higher than that of RKO and SW-480 cells, respectively. Apoptosis was evaluated by flow cytometry, where HT-29 cells showed the highest levels of early and total apoptosis, caspases activity was confirmed and necrosis was discarded. The effect on cell cycle arrest was shown in the G0/G1 phase. Specific apoptosis-related gene expression was determined, where an increase in p53 and a decrease in Bcl-2 were observed. Expression of p53 gene showed the maximum level at $8 \mathrm{~h}$ with an important decrease at 12 and $24 \mathrm{~h}$, also the phosphorylated p53(ser46) increased at $8 \mathrm{~h}$. Our results show that TBLF induces apoptosis in colon cancer cells by p-p53(ser46) involvement. Further studies will focus on studying the specific signal transduction pathway.
\end{abstract}

Keywords: apoptosis; colon cancer; lectins; p53; Phaseolus acutifolius

\section{Introduction}

The development of new therapies against colon cancer is gaining great importance in the research of natural products. Among plant compounds that have been studied because of their anticancer effects, lectins are being strongly considered. They are glycoproteins with the ability to recognize specific cell membrane carbohydrates [1,2]. Some plant lectins have shown differential cytotoxic effects on cancer cell lines given the specific changes in cell membrane glycosylation patterns $[3,4]$. The cytotoxic effects of plant lectins on cancer cell lines are related to their high specificity to cell membrane carbohydrates [5].

The specificity on different tumor cell lines could reflect different progression stages [6]. Some lectins can be internalized, causing cell death through ribosomal inactivation, or they can initiate signaling cascades that lead to apoptosis [5,7]. The most recognized mechanisms of action are the following: (1) At a physiological level, lectin-lymphocyte binding has been observed as well as release of blood cytokines, activation and release of spleen lymphocytes, activation of NK cells and macrophages, production of antiangiogenic factors, combination of intestinal hyperplasia and antiangiogenic effects reducing nutrient availability and cytotoxic effects on tumor cells [8,9]. (2) At the biochemical and molecular level, different mechanisms of action are proposed. One mechanism 
describes the binding of lectins to surface adhesion molecules that participate in a wide variety of transduction signals important for cell regulation. A second mechanism suggests that lectins affect the fundamental cellular process for cell division [10,11]. (3) A third level explains that lectin induces apoptosis in several ways: dependent on the intracellular activation of caspase-8/FLICE, the activation of caspase- 3 and Poly (ADP-ribose) Polymerases (PARP) cleavage, the activation of Bax (pro-apoptotic protein) and the inhibition of both Bcl-2 (apoptosis suppressor) and telomerase [5,11-14]. It is important to note that it is not an indispensable requirement for lectin to be internalized, since apoptotic effects can be caused by the interaction of lectin with cell membrane receptors.

Some lectins have been studied against colon cancer because of their effects on cell growth and promotion of cell death in different cell lines $[13,15,16]$, such as lectins of Arisaema helleborifolium (AHL), Arisaema tortuosum (ATL), Arachis hypogaea (PNA), Viscum album (VAL, VAA, VAA-1), Sauromatum venosum (SVA), Phaseolus vulgaris L. (PVA) and Vicia faba (VFA) $[4-6,8,14,15,17]$. A Tepary bean (Phaseolus acutifolius) lectin fraction (TBLF) has shown differential cytotoxic effects on breast, cervix and colon cancer cell lines as well as on non-malignant cells from the intestinal tract $[15,18]$. Similar effects were observed with other Tepary bean lectin fractions on different colon cancer cell lines $[19,20]$. In vivo studies have reported that TBLF $(50 \mathrm{mg} / \mathrm{kg}$ by intragastric administration for six weeks every third day) exhibits low toxicity, good tolerability and activates the immune system [21,22]. Between the observed adverse effects are loss of body weight, small intestinal villus and colonic crypt atrophy and exocrine pancreas hypertrophy, without systemic adverse effects. Negative effects could be reversible after a recovery period [8]. When TBLF was tested against colon cancer (chemically induced using dimethylhydrazine (DMH) or azoxymethane (AOM) in rats), early tumorigenesis inhibition was linked with modulation of apoptotic pathways [23]. The present work focuses on the evaluation of the apoptotic effect of TBLF on colon cancer cells, mainly by studying molecular mechanisms.

\section{Results}

\subsection{Concentration-Response Study and $L C_{50}$ Determination}

Concentration-response curves were obtained for each cell line, the TBLF-LC 50 values were $402 \mu \mathrm{g} / \mathrm{mL}$ for HT-29 cells, $49.2 \mu \mathrm{g} / \mathrm{mL}$ for RKO cells and $4.7 \mu \mathrm{g} / \mathrm{mL}$ for SW-480 cells (Figure 1). Our results suggest that TBLF is able to recognize cancer cells in a differential manner, provoking specific cytotoxic effects, even in cells derived from the same pathology. This differential effect was previously demonstrated for TBLF $[15,24]$. These results show that HT-29 cells were almost 10 times and 100 times more resistant than RKO and SW-480 cells, respectively. One of the relevant differences between the cell lines was the expression of EGFR for SW-480 cells, which was the most sensitive cell line to TBLF effects $[5,6,13,14]$.
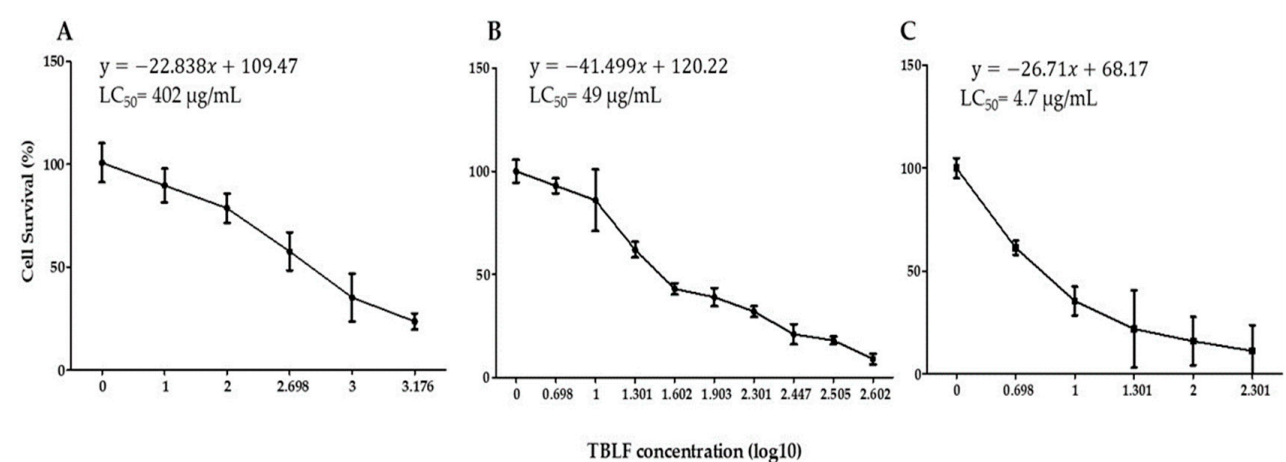

Figure 1. Concentration-response curves for HT-29, RKO and SW-480 cells. Cells were treated with different concentrations of Tepary bean lectin fraction (TBLF) for $24 \mathrm{~h}$. (A) HT-29 cells (1, 10, 100, 500, 1000 and $1500 \mu \mathrm{g} / \mathrm{mL}$ ). (B) RKO cells $(1,5,10,20,40,80,200,280,320$ and $400 \mu \mathrm{g} / \mathrm{mL}$ ). (C) SW-480 cells $(1,5,10,20,100$ and $200 \mu \mathrm{g} / \mathrm{mL})$. A linear regression of $\log 10$ of the TBLF concentration vs. cell survival (\%) was calculated in each case. 


\subsection{Effects on Cell Death and Cell Cycle Arrest}

Apoptosis induction by TBLF was confirmed by annexin V determination $(p \leq 0.05)$ using the $\mathrm{LC}_{50}$ for each cell line (Figure 2). A decrease in cell viability was determined in the three cell lines with respect to control cells $(p \leq 0.05)$. Early apoptosis was observed with a $21.7 \%$ increase in HT-29 cells, $15 \%$ in SW-480 cells and 3\% in RKO cells after $8 \mathrm{~h}$ treatment; late apoptosis had a 1\% increase in HT-29 cells, $7 \%$ in SW-480 cells and $25 \%$ in RKO cells. Total apoptosis (subtracting baseline apoptosis in control cells) was $22.77 \%$ for HT-29 cells, $23.3 \%$ for RKO cells and $18.31 \%$ for SW- 480 cells. Differential effects were observed again and the apoptosis mechanism was determined in HT-29 cells because this cell line showed the highest level of early and total apoptosis.
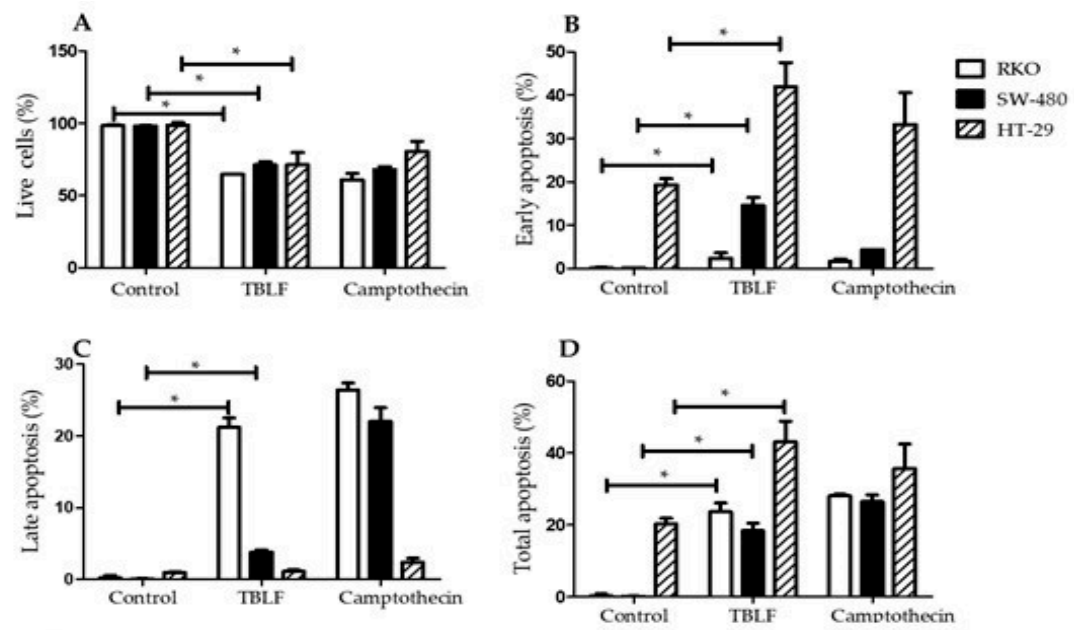

E
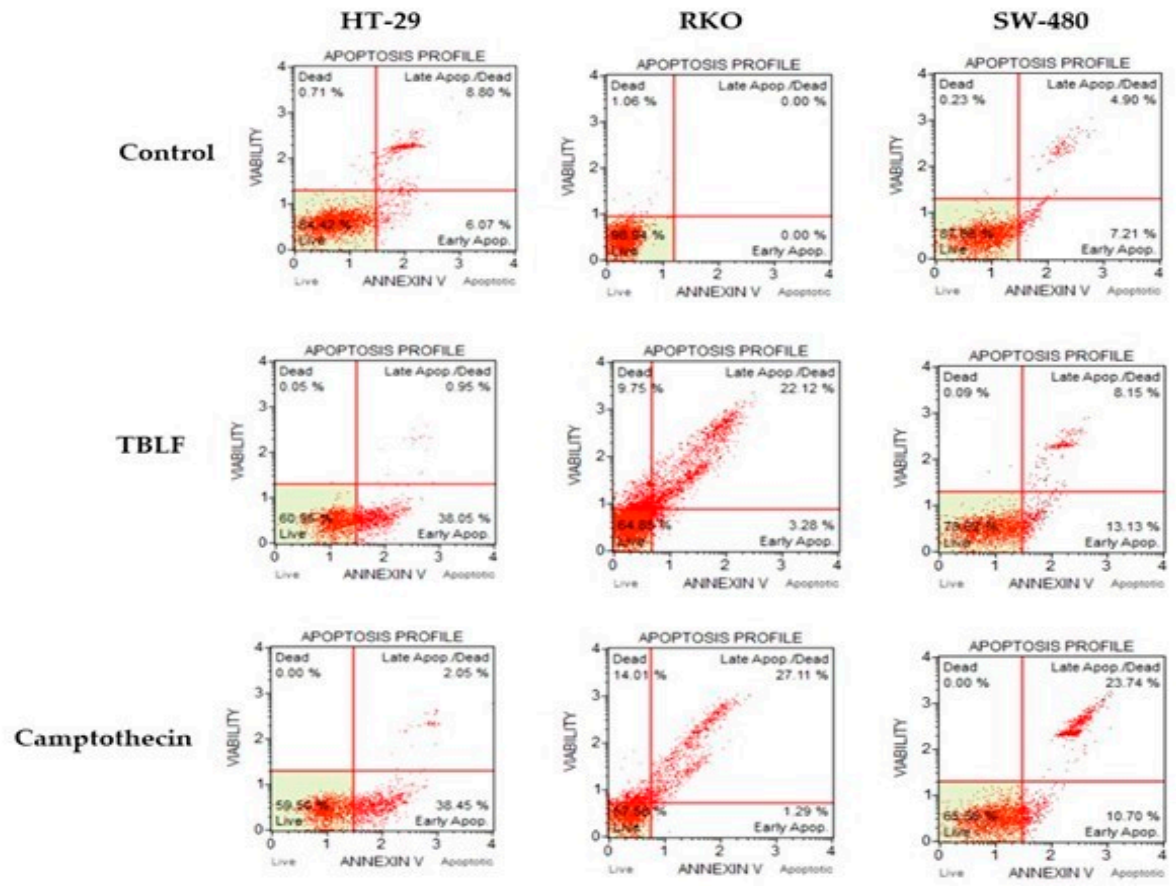

Figure 2. TBLF effect on apoptosis induction. Cells were treated for $8 \mathrm{~h}$ with the lethal concentration $\left(\mathrm{LC}_{50}\right)$. (A) Live cells, (B) early apoptosis, (C) late apoptosis, (D) total apoptosis. Camptothecin $(5 \mu \mathrm{M})$ was used as a positive control and $0.5 \%$ bovine serum albumin (BSA) as a negative control. (E) Flow cytometry representative dot plots are shown. $\left(^{*}\right)$ Statistically significant difference (Student $t$ test, $p \leq 0.05)$. 
The cytotoxic effect of TBLF was tested (Figure 3), where no necrotic effect after treatment with TBLF-LC 50 for $8 \mathrm{~h}$ was observed. Several studies have shown that induction of apoptosis by the activation of multiple caspases is a common mechanism of various lectins [25]. Caspase-3, an apoptosis effector protein, is currently considered a marker of this process [26]. In the present work, increases of $30 \%$ of caspase- 3 activity and $50 \%$ of total caspases activity were observed with respect to control cells $(p \leq 0.05)$ after $8 \mathrm{~h}$ treatment with TBLF-LC 50 . Cell cycle arrest showed an increase of $27.4 \%$ in the G0/G1 phase with respect to the negative control $(p \leq 0.05)$ (Figure 4$)$, but no effect was observed in $S$ and in $\mathrm{G} 2 / \mathrm{M}$ phases.
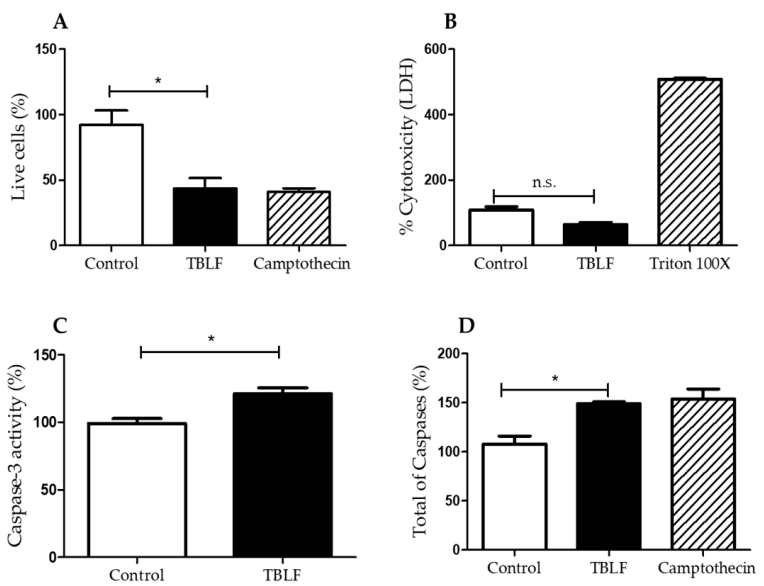

Figure 3. Effect of TBLF on necrosis and activation of caspases in HT-29 colon cancer cells. Cells were treated with the TBLF-LC 50 for $8 \mathrm{~h}$. (A) Cell viability (live cells), (B) lactate dehydrogenase release as necrosis marker, (C) caspase-3 activity, (D) total caspases activity. Camptothecin $(5 \mu \mathrm{M})$ was used as a positive control and $0.5 \%$ BSA as a negative control. $\left(^{*}\right)$ Statistically significant difference (Student $t$ test, $p<0.05)$.

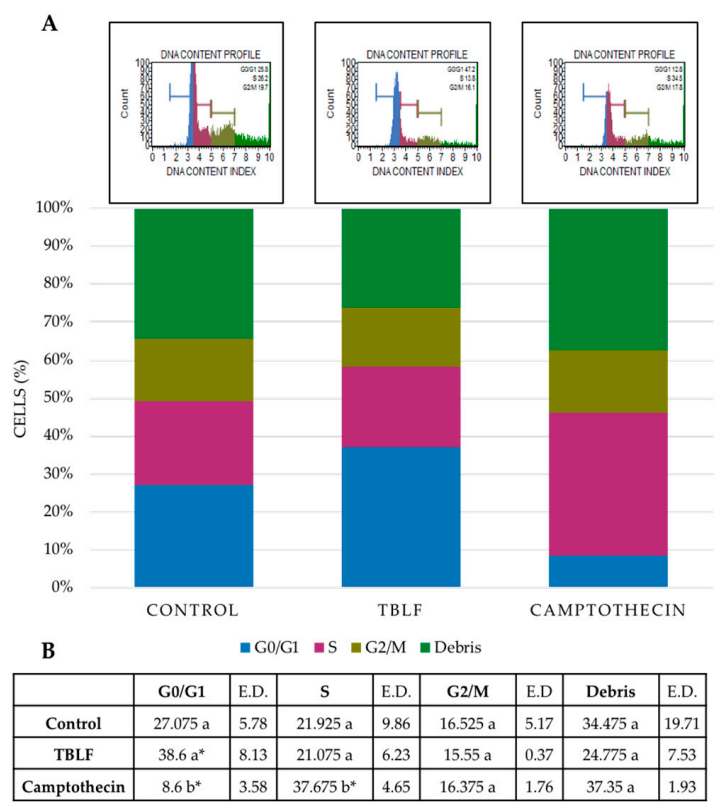

Figure 4. Effect of TBLF on cell cycle arrest on HT-29 colon cancer cells. Cells were treated with the TBLF-LC $_{50}$ for $8 \mathrm{~h}$. (A) Representative results of the cell cycle analysis; control group (BSA 0.5\%), TBLF-LC $_{50}$ and positive control camptothecin $(5 \mu \mathrm{M})$. (B) Graphic results obtained in the cell cycle analysis. One-way ANOVA was performed for each cell cycle phase. Small letters indicate significant differences (Tukey $p \leq 0.05$ ). (*) Indicates significant difference (Dunnett $p \leq 0.05$ ) with respect to the negative control group. 


\subsection{Apoptotic-Related Gene Expression and Phosphorylation of P53 in Ser46}

Significant changes in apoptotic gene expression were observed after TBLF-LC 50 treatment (Figure 5). A decrease in the expression of $\mathrm{Bcl} 2$ and an increase in p53 were determined, suggesting that TBLF mainly affected the anti-apoptotic pathways. Changes in p53 expression from 0 to $24 \mathrm{~h}$ showed and increase between 4 to $8 \mathrm{~h}$ with a significant decrease at 12 to $24 \mathrm{~h}$. Phosphorylation of p-p53(ser46) showed an increase, particularly during the first $8 \mathrm{~h}$ and subsequently was maintained. These results suggest that the specific activation effect of p53(ser46) is related to an increase of p53 gene expression, where the apoptotic signal is carried out.
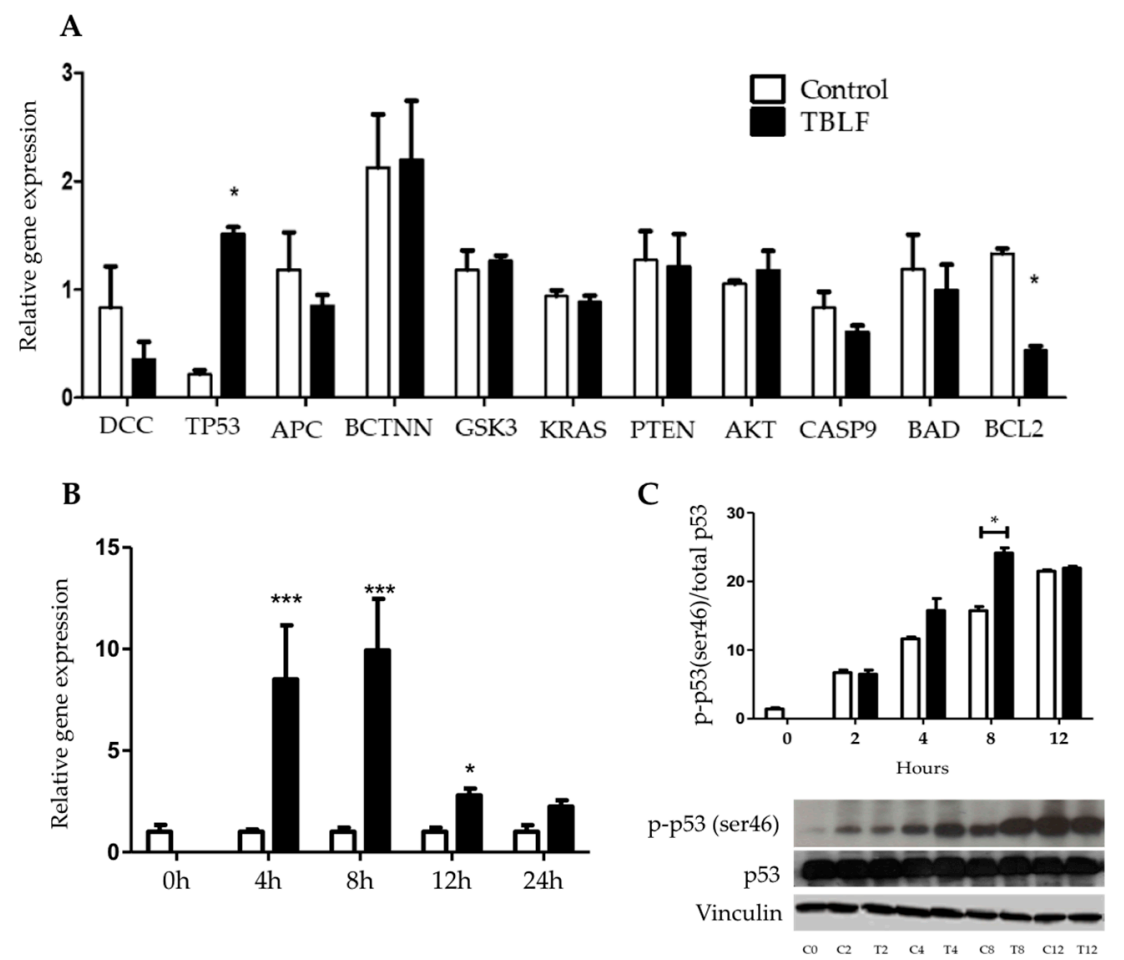

Figure 5. Effect of TBLF-LC 50 on apoptosis and cancer-signaling pathway gene expression in HT-29 colon cancer cells. (A) Cells were treated with the $\mathrm{LC}_{50}$ of TBLF for $8 \mathrm{~h}$. Relative gene expression for DCC, P53, APC, BCTNN, GSK-3, KRAS, PTEN, AKT, CAS9, BAD and BCL-2 with respect to B-actin. (B) Cells were treated with the TBLF-LC ${ }_{50}$ for 0, 4, 8, 12 and $24 \mathrm{~h}$. RT-qPCR evaluation for total p-53 gene respect to B-actin. (C) Western blot for total p53 and p-p53(ser46), graphic results are presented as p-p53(ser46)/total p-53. Student t test significant difference: $\left({ }^{*}\right) p \leq 0.05$ and $\left({ }^{* * *}\right) p \leq 0.001$.

\section{Discussion}

Previous studies have shown that TBLF exhibits differential cytotoxic effects on cancer cell lines [15]. In an in vivo study, this lectin fraction inhibited early malignant lesions in the colon when rats were treated with AOM as a cancer inductor and apoptosis was associated with a decrease in phosphorilated form of Akt (p-Akt) [23]. In order to know the apoptotic mechanism of action, TBLF was tested in three different colon cancer cell lines. LC $_{50}$ values were calculated and the results showed that HT-29 adenocarcinoma cells exhibited the most resistant phenotype, with an $\mathrm{LC}_{50}$ almost 10 and 100 times higher than that of RKO and SW-480 cells, respectively. HT-29 and RKO cells express a urokinase receptor, while SW-480 cells are positive for the epidermal growth factor receptor (EGFR). As SW-480 cells exhibited the lowest $\mathrm{LC}_{50}$, suggesting that they were the most sensitive cells and the fact that in the in vivo study a decrease in p-Akt was observed, it is probably that the EGFR may be involved in lectin-cell interactions [23]. The mechanisms reported for cytotoxic effects of plant lectins have been described in a wide range of cellular or physiological events such as activation of the immune system, induction of apoptosis by blocking membrane receptors, provoking mitochondrial imbalance and 
effects on some signal transduction pathways [1,4,27]. HT-29 cells showed the highest level of early and total apoptosis, while SW-480 cells exhibited the higher level of late apoptosis; this result agrees with the fact of the sensitiveness of SW-480 cells.

As HT-29 cells showed the highest levels of early and total apoptosis, the mechanism of action was evaluated using this cell line. Necrosis was discarded and this result agrees with the observed effects for other lectins, such as Phaseolus coccineus lectins, where it was determined that it achieves only an $11 \% \mathrm{LDH}$ increase after $24 \mathrm{~h}$ on L-929 fibroblasts [28]. In the same way, Clematis montana lectins were tested on L929 cells and gave very similar results to those reported for Phaseolus coccineus lectins [29]. Apoptosis was determined by total caspases and caspase- 3 activities, where TBLF increased both parameters by $50 \%$ and $30 \%$, respectively.

Apoptosis has been observed for other lectins such as Morus alba L., mulberry leaf lectins (MLL), where caspase-3 activity was increased in breast (MCF-7) and colon (HCT-15) cells in a similar way to cisplatin [11]. In the same way, mistletoe (Viscum album L.) lectins (VLL) induced caspase-3 activation in all leukemia cells [12] and similar effects were observed for lectins of the Chinese medicinal plant Astragalus membranaceus on K562 leukemia cells. Concanavalin A (Con A) and Sophora flavescens lectins (SFL) induced caspase-mediated cell death and caspase-3 activity in MCF-7 breast cancer cells in a concentration-dependent manner [13]. In the same way, the induction of apoptosis may have been orchestrated by mediating proteins such as NF- $\mathrm{kB}, \mathrm{p} 73$, Akt and $\mathrm{p} 53$, as well as by the processes of autophagy and oxidative stress [25].

Cell cycle showed arrest in the G0/G1 phase after TBLF treatment for $8 \mathrm{~h}$ in HT-29 cells. Such a result agrees with several studies that have shown the effect of lectins on cell cycle. An aqueous extract of Viscum articulatum Burm. F. (VAQE) stopped the cell cycle in G2/M in human leukemia cells and a Moringa oleifera seed lectin (MOSL) inhibited cell growth by arresting cell cycle in G2/M in Ehrlich-Lettre ascites carcinoma (EAC) cells [30]. Specifically, in the metastatic SW-620 colon cancer cell line, arrest was found in the $S$ phase and was time-dependent. Arrest was also induced by Rhizoctonia bataticola lectin (RBL) on cells with chromosomic structural loss [31]. Pea lectins provoke differential cell cycle arrest, dependent on the cell line, causing G2/M arrest in SW-48 and G0/G1 arrest in SW-480 cells, both from human colon cancer [32].

Shi et al., 2014 observed a dose-dependent effect of Con A lectin on the apoptotic promoter genes' Bid and Bax expression, proteins from the same family as Bad. However, it was observed that the expression of Bad did not show differences with respect to the control. Bad protein can be induced by Akt dephosphorylation, which has been observed to be affected by lectins of mistletoe VCL, in turn inducing apoptosis $[17,33]$. In the present work, a decrease in Bcl2 expression and an increase in p53 was determined. In the previous in vivo studies using TBLF, premalignant lesions in the colon were induced with AOM [23], but, in that moment, it was not possible to determine the effect of TBLF on p53 because AOM induction causes apoptosis-induced proliferation (AiP) that increases the p53 level [34,35].

Multiple signaling pathways having different activators and deactivators, as well as changes in its own pathway regulation, can affect the activity of p53. The participation of p53 as a transcription factor and as a tumor suppressor is very important in making decisions for the fate of a damaged cell, although the mechanisms by which it can be induced are not fully known [36,37]. Specific phosphorylation has been observed in various events of death and cell survival that trigger the specific activation of genes or regulate the permeability of the mitochondrial membrane. It has been observed that phosphorylation of p53 in ser15 and ser20 occur during slight damage to DNA, while phosphorylation in ser46 is involved with cell death [37-39]. Phosphorylation of p53 in ser46 is related to genotoxic stress and occurs after several hours of cell damage when the cell death process could be considered irreversible, which leads to cell cycle arrest and activation of control points $[39,40]$. It has been seen that some natural compounds promote the phosphorylation of p53 in ser46; such is the case of the induction of cell death by an extract of Zelkova serrata, which arrests the cell cycle in S-phase, activation of caspase- 8 and an increase in the amount of p-p53(ser46) in oral cancer cells in contrast to non-cancerous 
fibroblasts [41]. It has been observed that there is a genotoxic effect dependent on the activity of p-p53(ser46) induced by treatment with quercetin and curcumin [42].

In this sense, when p53 is phosphorylated in serine 46, it induces signaling pathways triggering apoptosis by stopping the cell cycle $[37,43,44]$. Our results suggest that p53 mutations in HT-29 cells do not affect the phosphorylation in ser46 and TBLF treatment increases the p-p53(ser46) level at $8 \mathrm{~h}$. Similar results have been observed in various studies for lectin-mediated cell death induction pathways $[27,45-48]$. Some other lectins affect the p53-mediated apoptosis pathway $[28,49,50]$.

\section{Materials and Methods}

\subsection{Obtaining TBLF}

Tepary bean (Phaseolus acutifolius) seeds were obtained from a local market in Hermosillo, Sonora, Mexico. A sample of Tepary bean was deposited and identified in the herbarium of Dr. Jerzy Rzedowski of the Natural Sciences Faculty, Querétaro Autonomous University, Santiago de Querétaro, México. The TBLF was obtained as described previously [51] with modifications [15,52]. Briefly, bean seeds were ground and degreased using a methanol/chloroform 2:1 solution, subsequently an aqueous extract was obtained using Tris buffer $\mathrm{pH}$ 6.8, precipitated with ammonium sulphate (40 to $70 \%$ saturation), centrifuged, dialyzed and separated by size-exclusion chromatography (Sephadex G75 column). Protein quantification was obtained by the Bradford method [53] and agglutination was tested [54] using glutaraldehyde-treated erythrocytes [55].

\subsection{Cell Culture and Concentration-Response Assay}

Colon cancer cells HT-29, RKO and SW-480 were obtained from the American Type Culture Collection $\left(\operatorname{ATCC}^{\circledR}\right)$ (Table 1) $[56,57]$. Cells were seeded in $60 \mathrm{~mm}$ diameter dishes with Dulbecco's modified Eagle's medium, DMEM, (GIBCO, New York, NY, USA), supplemented with $10 \%$ fetal bovine serum (FBS, Biowest, Nuaillé, France) at $37^{\circ} \mathrm{C}$ under a $5 \% \mathrm{CO}_{2}$ saturated water atmosphere, with medium changes every two days until confluence.

Table 1. Studied colon cancer cell lines.

\begin{tabular}{|c|c|}
\hline Cell Line & Characteristics \\
\hline HT-29 (АТCС®НТВ-38 & $\begin{array}{l}\text { Colorectal adenocarcinoma cells. Positive for c-myc, K-ras, H-ras, N-ras, Myb, } \\
\text { sis and fos oncogenes expression, N-myc oncogene expression was not } \\
\text { detected. p53 protein is overproduced with a G-A mutation in codon } 273 \\
\text { resulting in an Arg-His substitution. Express human adrenergic alpha2A } \\
\text { receptor, urokinase receptor (u-PAR) and moderate expression of vitamin D } \\
\text { receptor }\end{array}$ \\
\hline RKO (ATCC@CRL-2577'TM) & $\begin{array}{l}\text { Colon carcinoma cells. Wild-type p53 with high expression, positive for } \\
\text { urokinase receptor (u-PAR), but lack endogenous human thyroid receptor } \\
\text { nuclear receptor (h-TRbeta1). }\end{array}$ \\
\hline SW-480 (ATCC@CCL-228 ${ }^{\mathrm{TM}}$ ) & $\begin{array}{l}\text { Colorectal adenocarcinoma cells. Positive for the expression of c-myc, K-ras, } \\
\text { H-ras, N-ras, myb, sis and fos oncogenes, negative for N-myc oncogene } \\
\text { expression and for Matrilysin (a metalloproteinase associated with tumor } \\
\text { invasiveness), express high levels of p53 protein with a G-A mutation in } \\
\text { codon } 273 \text { of the p53 gene resulting in an Arg-His substitution and a C-T } \\
\text { mutation in codon } 309 \text { resulting in a Pro-Ser substitution. Positive for } \\
\text { epidermal growth factor receptor (EGFR). }\end{array}$ \\
\hline
\end{tabular}

Cytotoxic effects were determined by seeding $3 \times 10^{4}$ cells per well in 24-well dishes in DMEM medium with 10\% FBS for $48 \mathrm{~h}$. Then they were synchronized with DMEM at $\%$ FBS for $24 \mathrm{~h}$ and different concentrations of TBLF were added (HT-29 cells: 1, 10, 100, 500, 1000 and $1500 \mu \mathrm{g} / \mathrm{mL}$; RKO cells: 1, 5, 10, 20, 40, 80, 200, 280, 320 and $400 \mu \mathrm{g} / \mathrm{mL}$; and SW-480 cells: 1, 5, 10, 20, 100 and $200 \mu \mathrm{g} / \mathrm{mL}$ ) in DMEM/0.5\% FBS for $24 \mathrm{~h}$. The cells were collected after a 5 min incubation in 
trypsin/EDTA $(0.15 \mathrm{Mm} / 0.5 \mathrm{M}) /$ and a direct count was performed with a Newbauer chamber (Merk (BRAND®), Darmstadt, Germany). Cell number was determined following the formula (1) and the lethal concentrations $\left(\mathrm{LC}_{50}\right)$ were obtained by simple linear regression using the concentration $\log _{10} \mathrm{vs}$. survival percent.

$$
\text { Total cells }=\frac{(\text { Number of cells counted })}{(\text { Number of fields })} \times 10,000 \times m L \text { Suspension }
$$

\subsection{Evaluation of Apoptosis by Flow Cytometry}

Cell death evaluation was performed using the Muse ${ }^{\circledR}$ Annexin V and Dead Cell Assay Kit (Milipore cal. No: MCH 100105, Darmstadt, Germany) for the three cell lines. Briefly, cultures were maintained under the previous described conditions until they reached $70 \%$ confluence. Three groups were formed: negative control, incubated with $0.5 \%$ bovine serum albumin (BSA) in DMEM; treated group, incubated with the TBLF LC 50 (HT-29, $402 \mu \mathrm{g} / \mathrm{mL}$; RKO, $49 \mu \mathrm{g} / \mathrm{mL}$; SW- $480,4.7 \mu \mathrm{g} / \mathrm{mL}$ ) in $0.5 \%$ BSA DMEM; and a positive control, treated with camptothecin $5 \mu \mathrm{M}$ in DMEM 0.5\% BSA for $8 \mathrm{~h}$. Camptothecin is an antineoplastic alkaloid extracted from the Chinese tree Camptotheca acuminate. Its mechanism of action is recognized for cell cycle arrest in the $S$ phase, for promoting disruptions in the double strand of DNA and for stabilizing the topoisomerase I-DNA complex promoting apoptosis [57]. Cells were collected by trypsinization and concentrated by centrifugation $(6000 \times g$ for $5 \mathrm{~min})$, then they were washed with $1 \mathrm{Mm}$ PBS to disaggregate the clustered cells. Cells in each group were adjusted to $1 \times 10^{6}$ cells per $\mathrm{mL}$ in the culture medium and determinations were done following the supplier indications. The experiments were performed in triplicate in at least two independent experiments.

\subsection{Necrosis Determination by Lactate Dehydrogenase Assay}

Lactate dehydrogenase (LDH) is used as a marker of cell necrosis. HT-29 cells were cultured as previously described in 24-well plates and divided into three groups by triplicate: negative control, incubated with $0.5 \% \mathrm{BSA}$ in DMEM for $8 \mathrm{~h}$ at $37^{\circ} \mathrm{C}$; TBLF treated group, incubated with the $\mathrm{LC}_{50}$ $(402 \mu \mathrm{g} / \mathrm{mL})$ in $0.5 \%$ BSA-DMEM for $8 \mathrm{~h}$ at $37^{\circ} \mathrm{C}$; and a positive control, treated with $1 \%$ Triton 100X (JT Baker, cat No. X198-07, Madrid, Spain) in 0.5\% BSA-DMEM and incubated at $37^{\circ} \mathrm{C}$ for $30 \mathrm{~min}$. The conditioned media were obtained and the LDH-Cytotoxicity Assay kit (Biovision, cat No. K311-400, Milpitas, CA, USA) was used to evaluate the necrotic effect according to the manufacturer's instructions. Samples were read at $492 \mathrm{~nm}$ and the cytotoxicity percentage was calculated based on the enzymatic activity of LDH, according to the following formula (2):

$$
\% \text { Cytotoxicit }=\text { Treatment }- \text { Negative Control } \times \frac{100}{\text { Positive Control }}-\text { Negative Control }
$$

\subsection{Caspase- 3 Activity by Colorimetric Assay and Flow Cytometry Multi-Caspase Assay}

Caspase-3 activity was determined using the Caspase-3/CPP32 Colorimetric assay kit (BioVision, Milpitas, CA, USA) according to the manufacturer's protocol. HT-29 cells were cultured in $30 \mathrm{~mm}$ plates $\left(3 \times 10^{4}\right.$ cells/plate) for $8 \mathrm{~h}$ and then $\mathrm{LC}_{50}$ of TBLF $(402 \mu \mathrm{g} / \mathrm{mL})$ was added to each well. After incubation for $8 \mathrm{~h}$, cells were harvested, washed with phosphate-buffered saline (PBS) and suspended in cold lysis buffer. The cells were placed on ice for $20 \mathrm{~min}$ and lysed cells were centrifuged at $14,000 \times g$ for $15 \mathrm{~min}$. For the caspase assay, samples in assay buffer were mixed with caspase substrate (Ac-DEVD-pNA) in a 96-well plate. After overnight incubation at $37^{\circ} \mathrm{C}$, the absorbance of released p-nitroaniline was measured at $405 \mathrm{~nm}$ using a microplate reader (Spectra MAX 250, Molecular Devices). Caspase-3 activity was determined as follows (3):

$$
\text { Caspase }-3 \text { activity }=\frac{\text { Absorbance }}{\mu \mathrm{g} \text { of total Protain }} / \frac{\text { cells number }}{\mu \mathrm{g} \text { of total Protain }}
$$


The flow cytometry multi-Caspases assay (for caspases $-1,-3,-4,-5,-6,-7,-8$ and -9 ) was performed according the apoptosis assay by annexin V determination, as described previously, using the Muse ${ }^{\circledR}$ MultiCaspase- Kit (Cat. No. MCH100109, Merk Millipore Inc, Darmstadt, Germany). Briefly, HT-29 cells were incubated with $\mathrm{LC}_{50}$ for $8 \mathrm{~h}$, harvested and incubated with $5 \mu \mathrm{L}$ of Muse multi-caspase reagent working solution at $37^{\circ} \mathrm{C}$ for $30 \mathrm{~min}$. After the incubation, $150 \mu \mathrm{L}$ of Muse Caspase 7-AAD working solution was added to each sample. The activities of caspases were determined with the Muse ${ }^{\mathrm{TM}}$ Cell Analyzer (Merck Millipore, Darmstadt, Germany).

\subsection{Cell Cycle Analysis}

Flow cytometry was performed by seeding $3 \times 10^{5}$ cells in $60 \mathrm{~mm}$ culture dishes in $10 \%$ FBS-DMEM and incubating them at $37^{\circ} \mathrm{C}$ as previously described. When cultures reached $70 \%$ confluence, they were divided into three groups per triplicate: negative control, which was incubated in $0.5 \%$ BSA-DMEM; TBLF treated cells, added with TBLF LC $_{50}$ in $0.5 \%$ BSA-DMEM; and a positive control, using $5 \mu \mathrm{M}$ Camptothecin in $0.5 \%$ BSA-DMEM. All groups were incubated for $8 \mathrm{~h}$ and cells were collected by trypsinization and centrifugation $(6000 \times g$ for $5 \mathrm{~min})$. Cells were washed with $1 \times \mathrm{PBS} / 1 \mathrm{mM}$ EDTA to disaggregate cells and then fixed in $70 \%$ ethanol for $4 \mathrm{~h}$ at $-20^{\circ} \mathrm{C}$ following the instructions (Muse ${ }^{\circledR}$ Cell Cycle Assay Kit, Merk Millipore. Cat. No. MCH1006, Darmstadt, Germany). All assays were made in triplicate and with at least two independent experiments.

\subsection{Gene Expression Evaluation}

Treated cells were cultured as previously indicated for the flow cytometry assay. RNA extraction and purification was carried out by adding $400 \mu \mathrm{L}$ of Trizol (Invitrogen ${ }^{\mathrm{TM}}$, Carlsbad, CA, USA) to cells in $60 \mathrm{~mm}$ plates, homogenizing and kit instructions were followed (Direct-zol ${ }^{\mathrm{TM}}$ RNA MiniPrep RNA extraction kit was used, Zymo Research, Cat. No. R2052, Irvine, CA, USA). Samples were resuspended in nuclease-free water, total RNA was quantified and purity was determined by spectrophotometry using a NanoDrop ${ }^{\text {TM }}$ 2000/2000c spectrophotometer (Thermo Scientific, Waltham, MA, USA). cDNA synthesis was achieved for each $2 \mu \mathrm{g}$ of RNA added in $200 \mu \mathrm{L}$ microtubes and following the supplier's instructions for the kit (Maxima H Minus First Strand cDNA Synthesis, Thermo Scientific. Cat. No. K1652, Waltham, MA, USA) for a reaction volume of $40 \mu \mathrm{L}$ and a cycle of $25^{\circ} \mathrm{C}$ for $5 \mathrm{~min}, 65^{\circ} \mathrm{C}$ for $30 \mathrm{~min}$ and $85^{\circ} \mathrm{C}$ for $15 \mathrm{~min}$.

Primers were designed selecting genes related to the colorectal carcinogenesis signaling pathway. Genetic sequences were analyzed by the UCSC Genome Browser of the University of California [58] and primers were made by using the Primer3 page [59], seeking a TM of $60 \pm 2{ }^{\circ} \mathrm{C}$ (for $20 \pm 2 \mathrm{bp}$ ), a product size of 100-250 bp and CG $\geq 50 \%$. Sequences were synthesized by Sigma Laboratories (Aldrich, Mexico) (Table 2). The q-PCR reaction was performed in 96-well PCR plates using $3.4 \mu \mathrm{L}$ of nuclease-free water, $5 \mu \mathrm{L}$ of SYBR ${ }^{\circledR}$ Select Master Mix for CFX (Applied Biosystems, Cat. No. 4472942, Foster City, CA, USA) and $1 \mu \mathrm{L}$ of cDNA template for each reaction. A BioRad thermocycler (CFX96 model C1000, Bio-Rad Laboratories, Inc, Hercules, CA, USA) was used with the following conditions: $95{ }^{\circ} \mathrm{C}$ for $10 \mathrm{~min}\left(15 \mathrm{~s}\right.$ at $95^{\circ} \mathrm{C}, 30 \mathrm{~s}$ at $60^{\circ} \mathrm{C}, 30 \mathrm{~s}$ at $\left.72{ }^{\circ} \mathrm{C}\right)$ for 35 cycles and then held at $16^{\circ} \mathrm{C}$ until determination was done. 
Table 2. Primer sequences for Real-Time Polymerase Chain Reaction (qPCR).

\begin{tabular}{ccc}
\hline Gen Target & \multicolumn{1}{c}{ Forward } & Reverse \\
\hline B-CTNN & TGGACTTGATATTGGTGCCCA & GCCACCCATCTCATGTTCCA \\
\hline DCC & CCCCTGAAGTGTCTGAGGAG & AGCTGCTTCATGAGTCCTTCC \\
\hline PI3K & TGGAGCTGACCCAAATCCAT & TTCAAAGGCAGGGTTACTCC \\
\hline GSK3 & CTCCATCCAACCGTCTCTCA & GGTAGGTGTGGCATCGGTC \\
\hline CAS9 & CAAGAGTGGCTCCTGGTACG & TCCCTTTCACCGAAACAGCA \\
\hline BAD & TTCGGAGGATGAGTGACGAG & CAAGTTCCGATCCCACCAGG \\
\hline PTEN & GCCGTCAAATCCAGAGGCTA & GGATCAGAGTCAGTGGTGTCA \\
\hline AKT & CCTTCAAGCCCCAGGTCAC & CGCTCGCTGTCCACACAC \\
\hline TP53 & CCAACAACACCAGCTCCTCT & TCAGGAAGTAACACCATCGTAAG \\
\hline BCL-2 & GACTGAGTACCTGAACCGGC & GGCCAAACTGAGCAGAGTCT \\
\hline KRAS & TGTGATTTGCCTTCTAGAACAGT & ACACCCTGTCTTGTCTTTGCT \\
\hline
\end{tabular}

\subsection{Protein Determination by Western Blot}

Total protein was extracted from a pellet of approximately $5 \times 10^{6} \mathrm{HT}-29$ cells per time period $(2,4$, 8 and $12 \mathrm{~h}$ ) from the two groups: negative control (0.5\% BSA-DMEM) and TBLF LC $50(0.0402 \mathrm{mg} / \mathrm{mL})$. Cells were lysed using the CelLytic ${ }^{\mathrm{TM}}$ MT Cell Lysis Reagent (Sigma Aldrich, Cat. No. C3228, St. Louis, MO, USA) and total protein was determined [53]. Protein concentration was adjusted to $5 \mu \mathrm{g} / \mu \mathrm{L}$. The samples were boiled for $5 \mathrm{~min}$, separated on a $12 \%$ acrylamide $(30 \%) /$ bis-acrylamide $(1 \%)$ SDS-PAGE gel [60] and transferred to a $0.2 \mu \mathrm{m}$ pore nitrocellulose membrane (Bio-Rad Laboratories, Inc Hercules, California, CA, USA). Membranes were subsequently blocked with Blotting-Grade Blocker (Cat. No. 1706404, Bio-Rad Laboratories, Inc, Hercules, California, CA, USA) for $2 \mathrm{~h}$, incubated for $12 \mathrm{~h}$ with the primary rabbit antibody p53 (Cat. No. sc-98) or p-p53 (ser46) (Cat. No. sc-101764, Santa Cruz antibodies). The membrane was then washed (1X TBS/1\% Tween 20), incubated with the secondary antibody (Goat anti-rabbit IgG, Cat. No. PI-1000, Vector Laboratories) for $4 \mathrm{~h}$ and finally revealed using Amersham ECL Detection Reagents (Cat. No. RPN2105, General Electric, Boston, MA, USA). The images obtained after development were analyzed with the Image $J^{\circledR}$ program. All assays were made in triplicate and with at least two independent experiments.

\subsection{Statistics}

Results were analyzed using the SPSS v.26 program. For comparison for two groups a Student $t$ test and ANOVA one-way for three or more groups were used $(p \leq 0.05)$. Data were plotted using Prism Graph v.6 (La Jolla, CA, USA) comparing the means of each group \pm standard deviation. Western blot images were analyzed with the ImageJ program to de-merge the density of the bands.

\section{Conclusions}

The results indicate that TBLF induces death in colon cancer cell lines in a dose- and cell line-dependent manner. In HT-29 cells, TBLF induced G0/G1 arrest and apoptosis induction was determined by activation of caspases, particularly caspase- 3 and by flow cytometry. An increase in phosphorylation of p53 in serine 46, which is highly involved to the apoptotic process, was observed. Further works will focus on studying the effects of the signal transduction pathway, especially in the relationship between EGFR-Akt pathway and induction of apoptosis.

Author Contributions: U.M.-C. and F.J.L.-M. performed the in vitro experiments and the experimental analyses; R.C.-J. obtained TBLF; A.B.-L. and R.A.F.-M. participated in the study design and interpretation; and T.G.-G. directed the entire work. All co-authors participated in general discussions and interpretation of the results. All authors have read and agreed to the published version of the manuscript. 
Funding: This research was funded by Fondo para el Fortalecimiento de la Investigación de la Universidad Autónoma de Querétaro, 2018 (FOFI-UAQ 2018) and CONACyT for the fellowship for Ulisses Moreno-Celis. The finantial support for publication was kindly provided by PROFEXCE 2020.

Acknowledgments: Thanks for the facilities to the Molecular and Cellular Biology Laboratory, Microbiology Laboratory and the Small Species Veterinary Hospital, Natural Sciences Faculty, UAQ.

Conflicts of Interest: The authors declare no conflict of interest.

\section{References}

1. Estrada-Martínez, L.E.; Moreno-Celis, U.; Cervantes-Jiménez, R.; Ferriz-Martínez, R.A.; Blanco-Labra, A.; García-Gasca, T. Plant lectins as medical tools against digestive system cancers. Int. J. Mol. Sci. 2017, 18, 1403. [CrossRef] [PubMed]

2. Ghazarian, H.; Idoni, B.; Oppenheimer, S.B. A glycobiology review: Carbohydrates, lectins and implications in cancer therapeutics. Acta Histochem. 2011, 113, 236-247. [CrossRef] [PubMed]

3. Nonaka, M.; Ma, B.Y.; Murai, R.; Nakamura, N.; Baba, M.; Kawasaki, N.; Hodohara, K.; Asano, S.; Kawasaki, T. Glycosylation-dependent interactions of C-type lectin DC-SIGN with colorectal tumor-associated Lewis glycans impair the function and differentiation of monocyte-derived dendritic cells. J. Immunol. 2008, 180, 3347-3356. [CrossRef] [PubMed]

4. Ferriz-martinez, R.A.; Torres-arteaga, I.C.; Blanco-labra, A.; Garcia-gasca, T. The role of plant lectins in cancer trarment. In New Approaches in the Treatment of Cancer; Mejia-Vazquez, C., Ed.; Nova Science Publishers, Inc.: New York, NY, USA, 2010; pp. 71-89, ISBN 9781617283048.

5. Fu, L.; Zhou, C.; Yao, S.; Yu, J.-Y.; Liu, B.; Bao, J.-K. Plant lectins: Targeting programmed cell death pathways as antitumor agents. Int. J. Biochem. Cell Biol. 2011, 43, 1442-1449. [CrossRef] [PubMed]

6. Castillo-villanueva, A.; Abdullaev, F. Lectinas vegetales y sus efectos en el cáncer. Rev. Investig. Clínica 2005, $57,55-64$.

7. Han, S.-Y.; Hong, C.-E.; Kim, H.-G.; Lyu, S.-Y. Anti-cancer effects of enteric-coated polymers containing mistletoe lectin in murine melanoma cells in vitro and in vivo. Mol. Cell. Biochem. 2015, 408, 14-16. [CrossRef]

8. González De Mejía, E.; Prisecaru, V.I. Lectins as bioactive plant proteins: A potential in cancer treatment. Crit. Rev. Food Sci. Nutr. 2005, 45, 425-445. [CrossRef]

9. Timoshenko, A.V.; Gorudko, I.V.; Gabius, H.-J. Lectins from Medicinal Plants: Bioeffectors with Diverse Activities. In Phytochemicals. Biosyntehsis, Function and Application; Jetter, R., Ed.; Springer International Publishing: Cham, Switzerland, 2014; pp. 43-57, ISBN 978-3-319-04044-8.

10. Fang, E.F.; Pan, W.L.; Wong, J.H.; Chan, Y.S.; Ye, X.J.; Ng, T.B. A new Phaseolus vulgaris lectin induces selective toxicity on human liver carcinoma Hep G2 cells. Arch. Toxicol. 2011, 85, 1551-1563. [CrossRef]

11. Deepa, M.; Sureshkumar, T.; Satheeshkumar, P.K.; Priya, S. Purified mulberry leaf lectin (MLL) induces apoptosis and cell cycle arrest in human breast cancer and colon cancer cells. Chem. Biol. Interact. 2012, 200, 38-44. [CrossRef]

12. Delebinski, C.I.; Jaeger, S.; Kemnitz-Hassanin, K.; Henze, G.; Lode, H.N.; Seifert, G.J. A new development of triterpene acid-containing extracts from Viscum album L. displays synergistic induction of apoptosis in acute lymphoblastic leukaemia. Cell Prolif. 2012, 45, 176-187. [CrossRef]

13. Shi, Z.; Chen, J.; Li, C.; An, N.; Wang, Z.; Yang, S.; Huang, K.; Bao, J. Antitumor effects of concanavalin A and Sophora flavescens lectin in vitro and in vivo. Acta Pharmacol. Sin. 2014, 35, 248-256. [CrossRef] [PubMed]

14. Kabir, S.R.; Nabi, M.M.; Haque, A.; Zaman, R.U.; Mahmud, Z.H.; Reza, M.A. Pea lectin inhibits growth of Ehrlich ascites carcinoma cells by inducing apoptosis and G2/M cell cycle arrest in vivo in mice. Phytomedicine 2013, 20, 1288-1296. [CrossRef] [PubMed]

15. García-Gasca, T.; García-Cruz, M.; Hernandez-Rivera, E.; López-Matínez, J.; Castañeda-Cuevas, A.L.; Yllescas-Gasca, L.; Rodríguez-Méndez, A.J.; Mendiola-Olaya, E.; Castro-Guillén, J.L.; Blanco-Labra, A. Effects of Tepary bean (Phaseolus acutifolius) protease inhibitor and semipure lectin fractions on cancer cells. Nutr. Cancer 2012, 64, 1269-1278. [CrossRef] [PubMed]

16. Yau, T.; Dan, X.; Ng, C.C.W.; Ng, T.B. Lectins with potential for anti-cancer therapy. Molecules 2015, 20, 3791-3810. [CrossRef] [PubMed] 
17. Choi, S.H.; Lyu, S.Y.; Park, W.B. Mistletoe lectin induces apoptosis and telomerase inhibition in human A253 cancer cells through dephosphorylation of Akt. Arch. Pharm. Res. 2004, 27, 68-76. [CrossRef] [PubMed]

18. Rivera, E.H.; Olaya, E.M.; Blanco, A.; García, T. Efecto Citotóxico Diferencial de una Fracción Rica en Lectinas de Frijol Tépari (Phaseolus acutifolius) sobre Células Cancerígenas. In Proceedings of the $10^{\circ}$ Verano de la Ciencia de la Región Centro; Univeresidad Autónoma de Querétaro: Queretaro, Mexico, 2008; pp. 1-4.

19. Valadez-Vega, C.; Morales-González, J.; Sumaya-Martínez, M.; Delgado-Olivares, L.; Cruz-Castañeda, A.; Bautista, M.; Sánchez-Gutiérrez, M.; Zuñiga-Pérez, C. Cytotoxic and Antiproliferative Effect of Tepary Bean Lectins on C33-A, MCF-7, SKNSH, and SW480 Cell Lines. Molecules 2014, 19, 9610-9627. [CrossRef] [PubMed]

20. Valadez-Vega, C.; Alvarez-Manilla, G.; Riverón-Negrete, L.; García-Carrancá, A.; Morales-González, J.A.; Zuñiga-Pérez, C.; Madrigal-Santillán, E.; Esquivel-Soto, J.; Esquivel-Chirino, C.; Villagómez-Ibarra, R.; et al. Detection of cytotoxic activity of lectin on human colon adenocarcinoma (Sw480) and epithelial cervical carcinoma (C33-A). Molecules 2011, 16, 2107-2118. [CrossRef]

21. Alatorre-Cruz, J.M.; Pita-López, W.; López-Reyes, R.G.; Ferriz-Martínez, R.A.; Cervantes-Jiménez, R.; de Jesús Guerrero Carrillo, M.; Vargas, P.J.A.; López-Herrera, G.; Rodríguez-Méndez, A.J.; Zamora-Arroyo, A.; et al. Effects of intragastrically-administered Tepary bean lectins on digestive and immune organs: Preclinical evaluation. Toxicol. Reports 2018, 5, 56-64. [CrossRef]

22. Ferriz-Martínez, R.; García-García, K.; Torres-Arteaga, I.; Rodriguez-Mendez, A.J.; de Guerrero-Carrillo, M.J.; Moreno-Celis, U.; Ángeles-Zaragoza, M.V.; Blanco-Labra, A.; Gallegos-Corona, M.A.; Robles-Álvarez, J.P.; et al. Tolerability assessment of a lectin fraction from Tepary bean seeds (Phaseolus acutifolius) orally administered to rats. Toxicol. Reports 2015, 2, 63-69.

23. Moreno-Celis, U.; Lopez-Martinez, J.; Blanco-Labra, A.; Cervantes-Jimenez, R.; Estrada-Martinez, L.E.; Garcia-Pascalin, A.E.; Guerrero-Carrillo, M.D.J.; Rodriguez-Mendez, A.J.; Mejia, C.; Ferriz-Martinez, R.A.; et al. Phaseolus acutifolius Lectin Fractions Exhibit Apoptotic Effects on Colon Cancer: Preclinical Studies Using Dimethilhydrazine or Azoxi-Methane as Cancer Induction Agents. Molecules 2017, 22, 1670. [CrossRef]

24. García-Gasca, T.; Salazar-Olivo, L.A.; Mendiola-Olaya, E.; Blanco-Labra, A. The effects of a protease inhibitor fraction from tepary bean (Phaseolus acutifolius) on in vitro cell proliferation and cell adhesion of transformed cells. Toxicol. In Vitro 2002, 16, 229-233. [CrossRef]

25. Jiang, Q.-L.; Zhang, S.; Tian, M.; Zhang, S.-Y.; Xie, T.; Chen, D.-Y.; Chen, Y.-J.; He, J.; Liu, J.; Ouyang, L.; et al. Plant lectins, from ancient sugar-binding proteins to emerging anti-cancer drugs in apoptosis and autophagy. Cell Prolif. 2015, 48, 17-28. [CrossRef]

26. Chen, D.L.; Engle, J.T.; Griffin, E.A.; Miller, J.P.; Chu, W.; Zhou, D.; Mach, R.H. Imaging Caspase-3 Activation as a Marker of Apoptosis-Targeted Treatment Response in Cancer. Mol. Imaging Biol. 2015, 17, 384-393. [CrossRef] [PubMed]

27. Ribeiro, A.C.; Ferreira, R.; Freitas, R. Plant Lectins: Bioactivities and Bioapplications. In Studies in Natural Products Chemistry; Atta-ur-Rahman, Ed.; Elsevier B.V.: Amsterdam, The Netherlands, 2018; Volume 58, pp. 1-42, ISBN 9780444640567.

28. Chen, J.; Liu, B.; Ji, N.; Zhou, J.; Bian, H.J.; Li, C.Y.; Chen, F.; Bao, J.K. A novel sialic acid-specific lectin from Phaseolus coccineus seeds with potent antineoplastic and antifungal activities. Phytomedicine 2009, 16, 352-360. [CrossRef] [PubMed]

29. Peng, H.; Lv, H.; Wang, Y.; Liu, Y.H.; Li, C.Y.; Meng, L.; Chen, F.; Bao, J.K. Clematis montana lectin, a novel mannose-binding lectin from traditional Chinese medicine with antiviral and apoptosis-inducing activities. Peptides 2009, 30, 1805-1815. [CrossRef] [PubMed]

30. Asaduzzaman, A.K.M.; Hasan, I.; Chakrabortty, A.; Zaman, S.; Islam, S.S.; Ahmed, F.R.S.; Kabir, K.M.A.; Nurujjaman, M.; Uddin, M.B.; Alam, M.T.; et al. Moringa oleifera seed lectin inhibits Ehrlich ascites carcinoma cell growth by inducing apoptosis through the regulation of Bak and NF- $\mathrm{kB}$ gene expression. Int. J. Biol. Macromol. 2018, 107, 1936-1944. [CrossRef]

31. Hegde, P.; Rajakumar, S.B.; Swamy, B.M.; Inamdar, S.R. A mitogenic lectin from Rhizoctonia bataticola arrests growth, inhibits metastasis, and induces apoptosis in human colon epithelial cancer cells. J. Cell. Biochem. 2018, 119, 5632-5645. [CrossRef]

32. Islam, F.; Gopalan, V.; Lam, A.K.Y.; Kabir, S.R. Pea lectin inhibits cell growth by inducing apoptosis in SW480 and SW48 cell lines. Int. J. Biol. Macromol. 2018, 117, 1050-1057. [CrossRef] 
33. Lee-Yong, K.; Kim, W.; Lyu, S.; Park, W.-B.; Yoon, J.-W.; Jun, H.-S. Mechanisms involved in Korean mistletoe lectin-induced apoptosis of cancer cells. World J. Gastroenterol. 2007, 13, 2811-2818.

34. Ingaramo, M.C.; Sánchez, J.A.; Dekanty, A. Regulation and function of p53: A perspective from Drosophila studies. Mech. Dev. 2018, 154, 82-90. [CrossRef]

35. Fogarty, C.E.; Bergmann, A. Killers creating new life: Caspases drive apoptosis-induced proliferation in tissue repair and disease. Cell Death Differ. 2017, 24, 1390-1400. [CrossRef] [PubMed]

36. Meulmeester, E.; Jochemsen, A. p53: A Guide to Apoptosis. Curr. Cancer Drug Targets 2008, 8, 87-97. [CrossRef] [PubMed]

37. Feng, L.; Hollstein, M.; Xu, Y. Ser46 phosphorylation regulates p53-dependent apoptosis and replicative senescence. Cell Cycle 2006, 5, 2812-2819. [CrossRef] [PubMed]

38. D’Orazi, G.; Cecchinelli, B.; Bruno, T.; Manni, I.; Higashimoto, Y.; Saito, S.; Gostissa, M.; Coen, S.; Marchetti, A.; Del Sal, G.; et al. Homeodomain-interacting protein kinase-2 phosphorylates p53 at Ser 46 and mediates apoptosis. Nat. Cell Biol. 2002, 4, 11-19. [CrossRef]

39. Smeenk, L.; van Heeringen, S.J.; Koeppel, M.; Gilbert, B.; Janssen-Megens, E.; Stunnenberg, H.G.; Lohrum, M. Role of p53 Serine 46 in p53 Target Gene Regulation. PLoS ONE 2011, 6, e17574. [CrossRef]

40. Liebl, M.C.; Hofmann, T.G. Cell Fate Regulation upon DNA Damage: p53 Serine 46 Kinases Pave the Cell Death Road. BioEssays 2019, 41, 1900127. [CrossRef]

41. Kang, H.-J.; Jang, Y.-J. Selective apoptotic effect of Zelkova serrata twig extract on mouth epidermoid carcinoma through p53 activation. Int. J. Oral Sci. 2012, 4, 78-84. [CrossRef]

42. Sun, B.; Ross, S.M.; Joseph Trask, O.; Carmichael, P.L.; Dent, M.; White, A.; Andersen, M.E.; Clewell, R.A. Assessing dose-dependent differences in DNA-damage, p53 response and genotoxicity for quercetin and curcumin. Toxicol. Vitr. 2013, 27, 1877-1887. [CrossRef]

43. De Lange, J.; Ly, L.V.; Lodder, K.; Verlaan-De Vries, M.; Teunisse, A.F.A.S.; Jager, M.J.; Jochemsen, A.G. Synergistic growth inhibition based on small-molecule p53 activation as treatment for intraocular melanoma. Oncogene 2012, 31, 1105-1116. [CrossRef]

44. Song, X.; Dilly, A.K.; Choudry, H.A.; Bartlett, D.L.; Kwon, Y.T.; Lee, Y.J. Hypoxia promotes synergy between mitomycin $\mathrm{c}$ and bortezomib through a coordinated process of Bcl-xL phosphorylation and mitochondrial translocation of p53. Mol. Cancer Res. 2015, 13, 1533-1543. [CrossRef]

45. Yan, Q.; Li, Y.; Jiang, Z.; Sun, Y.; Zhu, L.; Ding, Z. Antiproliferation and apoptosis of human tumor cell lines by a lectin (AMML) of Astragalus mongholicus. Phytomedicine 2009, 16, 586-593. [CrossRef] [PubMed]

46. Miyoshi, N.; Koyama, Y.; Katsuno, Y.; Hayakawa, S.; Mita, T.; Ohta, T.; Kaji, K.; Isemura, M. Apoptosis induction associated with cell cycle dysregulation by rice bran agglutinin. J. Biochem. 2001, 130, 799-805. [CrossRef] [PubMed]

47. Bhutia, S.K.; Panda, P.K.; Sinha, N.; Praharaj, P.P.; Bhol, C.S.; Panigrahi, D.P.; Mahapatra, K.K.; Saha, S.; Patra, S.; Mishra, S.R.; et al. Plant lectins in cancer therapeutics: Targeting apoptosis and autophagy-dependent cell death. Pharmacol. Res. 2019, 144, 8-18. [CrossRef] [PubMed]

48. Liu, B.; Wu, J.M.; Li, J.; Liu, J.J.; Li, W.W.; Li, C.Y.; Xu, H.L.; Bao, J.K. Polygonatum cyrtonema lectin induces murine fibrosarcoma L929 cell apoptosis and autophagy via blocking Ras-Raf and PI3K-Akt signaling pathways. Biochimie 2010, 92, 1934-1938. [CrossRef] [PubMed]

49. Hostanska, K.; Vuong, V.; Rocha, S.; Soengas, M.S.; Glanzmann, C.; Saller, R.; Bodis, S.; Pruschy, M. Recombinant mistletoe lectin induces p53-independent apoptosis in tumour cells and cooperates with ionising radiation. Br. J. Cancer 2003, 88, 1785-1792. [CrossRef] [PubMed]

50. Takumi, S.; Komatsu, M.; Furukawa, T.; Ikeda, R.; Sumizawa, T.; Akenaga, H.; Maeda, Y.; Aoyama, K.; Arizono, K.; Ando, S.; et al. P53 plays an important role in cell fate determination after exposure to Microcystin-LR. Environ. Health Perspect. 2010, 118, 1292-1298. [CrossRef]

51. Bundy, H.F.; Westberg, N.J.; Dummel, B.M.; Becker, C.A. Purification and Partial Characterization of Prorennin. Biochemistry 1964, 3, 923-926. [CrossRef]

52. Torres Arteaga, I.; Castro Guillen, J.L.; Mendiola-Olaya, E.; Garcia-Gasca, T.; Angeles Zaragoza, M.; Garcia Santoyo, V.; Torres Castillo, J.A.; Aguirre, C.; Phinney, B.; Blanco-Labra, A. Characterization of Two Non-Fetuin-Binding Lectins from Tepary Bean (Phaseolus acutifolius) Seeds with Differential Cytotoxicity on Colon Cancer Cells. J. Glycobiol. 2016, 5, 1-7. [CrossRef]

53. Bradford, M.M. A rapid and sensitive method for the quantitation of microgram quantities of protein utilizing the principle of protein-dye binding. Anal. Biochem. 1976, 72, 248-254. [CrossRef] 
54. Jaffé, W. Hemagglutinins (Lectins). In Toxic Constituents of Plant Foodstuffs; Academic Press: New York, NY, USA, 1980; pp. 73-102.

55. Turner, R.H.; Liener, I.E. The use of glutaraldehyde-treated erythrocytes for assaying the agglutinating activity of lectins. Anal. Biochem. 1975, 68, 651-653. [CrossRef]

56. Sanger Institute Genome Research Limited Cell Lines Project v90. Available online: http://cancer.sanger.ac. uk/cosmic/ (accessed on 2 March 2018).

57. American Type Culture Collection American Type Culture Collection (ATCC): The Global Bioresource Center. Available online: http://www.atcc.org/ (accessed on 3 May 2018).

58. University of California. UCSC Genome Browser Home. Available online: https://genome.ucsc.edu/ (accessed on 10 August 2018).

59. Untergasser, A.; Cutcutache, I.; Koressaar, T.; Ye, J.; Faircloth, B.C.; Remm, M.; Rozen, S.G. Primer3 Input. Available online: http://primer3.ut.ee/ (accessed on 8 October 2018).

60. Laemmli, U.K. Cleavage of Structural Proteins during the Assembly of the Head of Bacteriophage T4. Nature 1970, 227, 680-685. [CrossRef] [PubMed]

(C) 2020 by the authors. Licensee MDPI, Basel, Switzerland. This article is an open access article distributed under the terms and conditions of the Creative Commons Attribution (CC BY) license (http://creativecommons.org/licenses/by/4.0/). 